\title{
KEKERASAN TERHADAP ANAK
}

\author{
Sumiadji Asy'ary ${ }^{1}$ \\ e-mail: sumasyari87@gmail.com \\ STAI TARUNA SURABAYA
}

\begin{abstract}
Abstrak : Sering kali orang tua melakukan tindak kekerasan terhadap anak, meskipun tujuannya mendidik tapi kebanyakan orang tua salah langkah, akibatnya banyak sekali anak-anak yang mengalami trauma dan perkembangan anak menjadi memburuk akibat dari adanya kekerasan yang diberikan sewaktu mereka masih kecil. Banyak kebiasaan yang sering membahayakan bagi anak akan tetapi orang tua sering tidak menyadarinya,sehingga banyak sekali anak yang mendapat dampak yang buruk dari kebiasaan tersebut. Sebaiknya orang tua harus lebih hati-hati dalam mengambil sikap terhadap anak didiknya, dan hal ini sangat penting karna sangat berpengaruh bagi perkembangan anak kedepannya.meskipun kebanyakan orang tua banyak yang tidak sadar bahwa apa yang diberikan terhadap anak itu sangat berpengaruh bagi anak baik dari segi mental maupun fisiknya.
\end{abstract}

Kata Kunci : Kekerasan, Anak

\section{A. PENDAHULUAN}

Di tengah budaya masyarakat Indonesia, hukuman fisik adalah suatu yang sangat wajar dan masih banyak para orang tua atau para pendidik yang dalam memberikan hukuman fisik.

Seorang teman yang menceritakan pengalaman traumatisnya, dari pengalamannya seorang teman yang pernah mendapatkan hukuman fisik, pada suatu hari saat guru mengajarkan suatu pelajaran tertentu, sang murid disuruh maju kedepan untuk mengerjakan soal yang diberikan oleh guru.

Setelah mengerjakan soal dan diperiksa oleh guru ternyata jawabannya salah semua, tanpa berpikir panjang guru langsung memberi hukuman dengan memukulkan kayu rotan dipunggungnya. Bahkan banyak bentuk hukuman-hukuman lain yang justru tidak mendidik.

Pandangan penulis hukuman fisik yang adalah warisan budaya kolonial, sejarah pendidikan kolonial sangat berpengaruh, yakni pendidikan kolonial disini membangun pola pendidikan tradisional yang melegitimasikan aksi hukuman fisik, berupa suatu

\footnotetext{
${ }^{1}$ Dosen Tetap Stai Taruna Surabaya
} 
tindakan yang menyakiti secara fisik dengan tujuan untuk menekan perilaku negatif seorang anak atau orang lain

Orang-orang yang dijajah tidak diperlakukan sebagai manusia, tetapi lebih kepada benda. Jelasalah bahwa ternyata begitu besar pengaruh dari kolonialisme. Colonial jaman belanda kental dengan perbudakan yakni dengan melihat adanya legitimasi majikan untuk menghukum budak bila melakukan kesalahan, adanya nilai superior dan inferior dalam pengambilan keputusan seorang majikan tidak memperhitungkan nilai-nilai demokratis.

Budaya majikan disini jelas mempunyai kewibawaan dan status social yang berbeda dengan masyarakat lainnya. Kalau melihat realiatas sekarang akar kekerasan tersebut masih ada, seperti dengan halnya guru menghukum muridnya, posisi orang tua dalam mendidik anak dalam keluarga, golongan ningrat yang melakukan kekerasan terhadap budak dan pejabat pemerintahan menekan rakyatnya, yang juga memiliki legitimasi untuk menerapkan penghakiman dan distribusi sanksi sepihak tanpa proses demokrasi.

Menurut hasil pengaduan yang diterima KOMNAS perlindungan Anak, bahwa pemicu kekerasan terhadap anak yang terjadi diantaranya adalah:

1) Kekerasan dalam rumah tangga dan anak yang menjadi sasaran.

2) Disfungsi keluarga yaitu peran orang tua tidak sejalan sebagaimana seharusnya.

3) Faktor ekonomi yaitu kekerasan timbul karna tekanan ekonomi.

4) Pandangan keliru tentang posisi anak dalam keluarga,dengan anggapan bahwa anak tidak tahu apa-apa.

Disamping itu, faktor penyebab kekerasan pada anak yakni terinspirasi dari tayangan-tayangan televisimaupun media lainnya yang tersebar dilingkungan masyarakat.yang sangat mengejutkan ternyata62\% tayangan televisi maupun media lainnya telah membangun dan menciptakan prilaku kekerasan (Tempo,2006).

Menurut sitohang (2004), penyebab munculnya kekerasan pada anak adalah

1) Stress berasal dari anak yaitu kondisi anak yang berbeda ,mental yang berbeda atau anak angkat.

2) Stress keluarga yaitu kemiskinan pengangguran mobilitas, isolasi, perumahan yang tidak memadai,anak yang tidak diharapkan dan lain sebagainya. 
3) Stress berasal dari orang tua rendah diri waktu kecil mendapat perlakuan salah,depresi,harapan pada anak yang tidak realistis kelainan karakter/gangguan jiwa .

Unicef (1986) mengemukakan ada dua faktor yang melatarbelekangi munculnya kekerasan anak oleh orangtuanya.Faktor tersebut masing-masing berasal baik dari orang tua maupun anak sendiri.Dua faktor tersebut antara lain:

1) Orang tua pernah menjadi korban penganiayaan anak dan terpapar oleh kekerasan dalam rumah,orang tua yang kondisi kehidupannya penuh dengan stress, seperti rumah yang sesak ,kemiskinan, orang yang menyalahgunakan NAPZA, orang tua yang mengalami gangguan jiwa seperti depresi atau psikotik atau gangguan kepribadian.

2) Anak yang prematur,anak yang retardasi mental,anak yang cacat fisik,anak yang suka menangis hebat atau banyak tuntutan.Berdasarkan uraian tersebut baik orang tua maupun anak sama-sama berpengaruh pada timbulnya kekerasan pada anak.

Rahmat (2003) beranggapan kekerasan pada anak-anak, bukan hanya merupakan problem personal,jika hanya menimpa segelintir anak-anak saja dapat dilacak pada sebab'-sebab psikologis dari individu yang terlibat.

Tetapi jika memperlakukan dengan cara mengerjakan anak kecil dalam jangka panjang ,menelantarkan mereka,atau menyakiti dan menyiksa anak itu terdapat secara meluas di tengah-tengah masyarakat maka berhadapan dengan masalah sosial.penyebabnya tidak lagi dilacak pada sebab'-sebab individual.melacaknya pada nilai pola intraksi sosial ,struktur sosial ekonomi dan pranata sosial.Pemecahannya memerlukan tindakan kolektif dari seluruh anggota masyarakatoleh karna itu penulis akan membahas lebih dalam pada bab-bab selanjutnya.

\section{B. MEMAHAMI KEKERASAN}

Pengertian kekerasan terhadap anak adalah segala sesuatu yang membuat anak tersiksa, baik secara fisik, psikologis maupun mental. Oleh para ahli, pengertian kekerasan terhadap anak ini banyak definisi yang berbeda-beda. Di bawah ini akan diberikan beberapa definisi pengertian kekerasan terhadap anak oleh beberapa ahli.

Kempe, dkk (1962) dalam Soetjiningsih (2005) memberikan pengertian kekerasan terhadap anak adalah timbulnya perlakuan yang salah secara fisik yang 
ekstrem kepada anak-anak.Sementara Delsboro (dalam Soetjiningsih, 1995) menyebutkan bahwa seorang anak yang mendapat perlakuan badani yang keras, yang dikerjakan sedemikian rupa sehingga menarik perhatian suatu badan dan menghasilkan pelayanan yang melindungi anak tersebut.

Fontana (1971) dalam Soetjiningsih (2005) memberikan pengertian kekerasan terhadap anak dengan definisi yang lebih luas yaitu memasukkan malnutrisi dan menelantarkan anak sebagai stadium awal dari sindrom perlakuan salah, dan penganiayaan fisik berada pada stadium akhir yang paling berat dari spektrum perlakuan salah oleh orang tuanya atau pengasuhnya.

David Gill (dalam Sudaryono, 2007) mengartikan perlakuan salah terhadap anak adalah termasuk penganiayaan, penelantaran dan ekspoitasi terhadap anak, dimana hal ini adalah hasil dari perilaku manusia yang keliru terhadap anak. Bentuk kekerasan terhadap anak tentunya tidak hanya berupa kekerasan fisik saja, seperti penganiayaan, pembunuhan, maupun perkosaan, melainkan juga kekerasan non fisik, seperti kekerasan ekonomi, psikis, maupun kekerasan religi.

Kekerasan terhadap anak menurut Andez (2006) adalah segala bentuk tindakan yang melukai dan merugikan fisik, mental, dan seksual termasuk hinaan meliputi: Penelantaran dan perlakuan buruk, Eksploitasi termasuk eksploitasi seksual, serta trafficking/ jual-beli anak. Sedangkan Child Abuse adalah semua bentuk kekerasan terhadap anak yang dilakukan oleh mereka yang seharusnya bertanggung jawab atas anak tersebut atau mereka yang memiliki kuasa atas anak tersebut, yang seharusnya dapat di percaya, misalnya orang tua, keluarga dekat, dan guru.

Sedangkan Nadia (2004) memberikan pengertian kekerasan terhadap anak sebagai bentuk penganiayaan baik fisik maupun psikis. Penganiayaan fisik adalah tindakan-tindakan kasar yang mencelakakan anak, dan segala bentuk kekerasan fisik pada anak yang lainnya. Sedangkan penganiayaan psikis adalah semua tindakan merendahkan atau meremehkan anak. Alva menambahkan bahwa penganiayaan pada anak-anak banyak dilakukan oleh orangtua atau pengasuh yang seharusnya menjadi seorang pembimbing bagi anaknya untuk tumbuh dan berkembang.

Menurut WHO (2004 dalam Lidya, 2009) kekerasan terhadap anak adalah suatu tindakan penganiayaan atau perlakuan salah pada anak dalam bentuk menyakiti fisik, emosional, seksual, melalaikan pengasuhan dan eksploitasi untuk kepentingan 
komersial yang secara nyata atau pun tidak dapat membahayakan kesehatan, kelangsungan hidup, martabat atau perkembangannya, tindakan kekerasan diperoleh dari orang yang bertanggung jawab, dipercaya atau berkuasa dalam perlindungan anak tersebut.

Berdasarkan beberapa pengertian di atas dapat disimpulkan pengertian kekerasan terhadap anak adalah perilaku salah baik dari orangtua, pengasuh dan lingkungan dalam bentuk perlakuan kekerasan fisik, psikis maupun mental yang termasuk didalamnya adalah penganiayaan, penelantaran dan ekspoitasi, mengancam dan lain-lain terhadap terhadap anak. ${ }^{2}$

Kekerasan terhadap anak dalam arti kekerasan dan penelantaran adalah: "semua bentuk perlakuan menyakitkan secara fisik maupun emosional, pelecehan seksual, penelantaran, eksploitasi komersial atau eksploitasi lain yang mengakibatkan cidera atau kerugian nyata ataupun potensial terhadap kesehatan anak, kelangsungan hidup anak, tumbuh kembang anak atau martabat anak yang dilakukan dalam konteks hubungan tanggung jawab, kepercayaan, atau kekuasaan. Sementara pengertian menurut UU Perlindungan Anak pasal 13 yang dimaksud kekerasan terhadap anak adalah "diskriminasi, eksploitasi baik fisik maupun seksual, penelantaran, kekejaman, kekerasan, dan penganiayaan, ketidakadilan, dan perlakuan salah lainnya.”.

Menurut WHO ada beberapa jenis kekerasan pada anak, yaitu;

a) Kekerasam fisik

Kekerasan fisik adalah tindakan yang menyebabkan rasa sakit atau potensi menyebabkan sakit yang dilakukan oleh orang lain, dapat terjadi sekali atau berulang kali. Kekerasan fisik misalnya; dipukul, ditendang. dijewer/dicubit, dsb.

b) Kekerasan seksual

Kekerasan adalah ketertiban anak dalam kegiatan seksual yang tidak dipahaminya. Kekerasan seksual dapat berupa perlakuan tidak senonoh dari orang lain, kegiatan yang menjurus pada pornografi, perkataan-perkataan porno, dan melibatkan anak dalam bisnis prostitusi, dsb.

c) Kekerasan emosional

\footnotetext{
${ }^{2}$ http://www.psychologymania.com/2012/07/pengertian-kekerasan-terhadap-anak.html
} 
Kekerasan emosional adalah segala sesuatu yang dapat menyebabkan terhambatnya perkembangan emosional anak. Hal ini dapat berupa kata-kata yang mengancam/ menakut-nakuti anak, dan lain sebagainya.

d) Tindakan pengabaian \& penelantaran

Tindakan pengabaian dan penelantaraan adalah ketidakpedulian orang tua atau orang yang bertanggung jawab atas anak pada kebutuhan mereka, seperti: pengabaian kesehatan anak, pendidikan anak, terlalu mengekang anak, dsb.

e) Kekerasan ekonomi

Kekerasan ekonomi (eksploitasi komersial) adalah penyalahgunaan tenaga anak untuk bekerja dan kegiatan lainnya demi keuntungan orang tuanya atau orang lain, seperti menyuruh anak bekerja secara seharian dan menjuruskan anak pada pekerjaan-pekerjaan yang seharusnya belum dijalaninya.

\section{DAMPAK KEKERASAN TERHADAP ANAK}

Disamping segala bentuk penganiayaan yang dialami anak sebagaimana yang tercantum diatas, ada beberapa hal yang mempunyai andil dalam besar / kecilnya dampak yang diderita anak, antara lain:

a) Faktor usia anak. Semakin muda usia anak maka akan menimbulkan akibat yang lebih fatal.

b) Siapa yang terlibat. Jika yang melakukan penganiayaan adalah orang tua, ayah atau ibu tiri, atau anggota keluarga maka dampaknya akan lebih parah daripada yang melakukannya orang yang tidak dikenal.

c) Seberapa parah. Semakin sering dan semakin buruk perlakuan yang diterima anak akan memperburuk kondisi anak.

d) Berapa lama terjadi. Semakin lama kejadian berlangsung akan semakin meninggalkan trauma yang membekas pada diri anak.

e) Jika anak mengungkapkan penganiayaan yang dialaminya, dan menerima dukungan dari orang lain atau anggota keluarga yang dapat mencintai, mengasihi dan memperhatikannya maka kejadiannya tidak menjadi lebih parah sebagaimana jika anak justru tidak dipercaya atau disalahkan.

f) Tingkatan sosial ekonomi. Anak pada keluarga dengan status sosial ekonomi rendah cenderung lebih merasakan dampak negatif dari penganiayaan anak. 
Dalam beberapa kasus anak-anak yang mengalami penganiayaan tidak menunjukkan gejala-gejala seperti diatas. Banyak faktor lain yang berpengaruh seperti seberapa kuat status mental anak, kemampuan anak mengatasi masalah dan penyesuaian diri. Ada kemungkinan anak tidak mau menceritakannya karena takut diancam, atau bahkan dia mencintai orang yang melakukan penganiyaan tersebut. Dalam hal ini anak biasanya menghindari adanya tindakan hukum yang akan menimpa orang-orang yang dicintainya, seperti orang tua, anggota keluarga atau pengasuh. ${ }^{3}$

Kekerasan yang dialami anak dapat berakibat langsung pada diri sang anak. bila seorang anak mengalami kekerasan secara fisik, dampak langsung yang akan dialaminya diantaranya dapat mengakibatkan kematian, patah tulang/ luka-luka, dan pertumbuhan fisiknya pun berbeda dengan teman sebayanya. Sedangkan dampak jangka panjang yang dapat dialami anak yang mendapat kekerasan adalah akan munculnya perasaan malu/menyalahkan diri sendiri, cemas/depresi, kehilangan minat untuk bersekolah, stres pasca-trauma seperti terus-menerus memikirkan peristiwa traumatis yang dialaminya, dan dapat pula tumbuh sebagai anak yang mengisolasi diri sendiri dari lingkungan di sekitarnya. ${ }^{4}$

Adapun kebiasaan yang berbahaya bagi anak ada 15 macam:

a) Asma (asal marah)

b) TBC (Terlalu bawel dan cerewet)

c) Kusta (Kurang sentuhan cinta)

d) Kudis (Kurang disiplin)

e) Pikun (pikiran kuno)

f) Aids (Asal itu duit sikat)

g) Bisulan (Bapak ibu sibuk urusan keluarga terlantar)

h) Kurapan (Kurang respon atas pencapaian anak)

i) Polip (Pola asuh inkonsisten dan permisif)

j) Batuk (Bicara asal nyeletuk)

k) Luka (Lupa Kebesaran Allah)

1) Gatal(Gangguan mental)

m) Tipus (Tidak peduli urusan sekolah)

\footnotetext{
${ }^{3} \mathrm{http}: / / \mathrm{www}$. smallcrab.com/anak-anak/550-beberapa-jenis-kekerasan-pada-anak

${ }^{4}$ http://iin-green.web.id/2010/05/08/definisi-kekerasan-terhadap-anak/
} 
n) Mimisan (Mikir-mikir dan cari-cari alasan)

o) Manja (menjaga jarak)

\section{BENTUK-BENTUK KEKERASAN TERHADAP ANAK}

Menurut keterangan Consultation On Child Abuse Prevention (WHO,1990), terdapat lima jenis perlakuan Kekerasan Terhadap Anak (KTA) antara lain :

1. Kekerasan Fisik :

Kekerasan yang mengakibatkan cedera fisik secara nyata maupun potensial terhadap anak, sebagai akibat dari interaksi atau tidak adanya interaksi yang layaknya berada dalam kendali orangtua atau orang dalam posisi hubungan tanggungjawab, kepercayaan atau kekuasaan.

2. Kekerasan Seksual :

Meliputi : eksploitasi seksual, prostitusi, pornografi, paksaan untuk melihat kegiatan seksual, memperlihatkan kemaluan kepada anak untuk tujuan kepuasan seksual, stimulasi seksual, perabaan, memegang kemaluan, hubungan seksual, incest, perkosaan, sodomi.

3. Kekerasan Emosional :

Perbuatan terhadap anak yang mengakibatkan gangguan kesehatan atau kelainan perkembangan fisik, mental, spiritual, moral dan sosial, seperti: membentak, menghardik, berkata-kata kasar kepada anak-anak.

4. Penelantaran Anak :

Kegagalan dalam menyediakan kebutuhan tumbuh kembang anak (kesehatan, pendidikan, perkembangan emosional, nutrisi, rumah, keamanan, pengasuhan) yang mengakibatkan gangguan kesehatan fisik, mental, moral, spiritual dan sosial, termasuk pula pengawasan dan perlindungannya.

5. Eksploitasi Anak :

Penggunaan anak dalam pekerjaan atau aktifitas lainnya, untuk keuntungan orang lain atau merugikan kesehatan disik, mental, perkembangan spiritual, moral dan sosial-emosional anak-anak. 
Bermacam jenis Kekerasan Terhadap Anak tersebut harus segera ditangani bersama, dengan memulai pencegahannya sedini mungkin dari lingkungan keluarga ataupun kerabat terdekat. ${ }^{5}$

Sementara yang dimaksud perlindungan khusus yaitu perlindungan yang diberikan kepada anak dalam situasi darurat, anak yang berhadapan dengan hukum, anak dari kelompok minoritas dan terisolasi, anak yang diekploitasi secara ekonomi dan /atau seksual, anak yang diperdagangkan, anak yang menjadi korban penyalahgunaan narkotika, alkohol, psikotropika, dan zat adiktif lainnya, dan bagi anak yang menjadi korban penculikan, korban kekerasan baik fisik maupun mental, anak yang cacat, dan juga bagi anak-anak yang ditelantarkan.

\section{E. KEBIASAAN BERBAHAYA BAGI ANAK}

Ada beberapa hal yang menjadi kebiasaan anak tetapi sangat berbahaya bagi anak kedepannya, yakni :

1. Asma (asal marah)

Penyakit asma tidak selalu serius dan harus selalu mendapatkan perawatan yang dirumah sakit.Bisa saja penyakit ini hanya gejala semusim yang bertahan hanya dalam waktu yang singkat.Tetapi jika asma ini tidak dikontrol dengan baik maka dapat dipastikan bahwa gejala asma ini dapat menggangu aktifitas seharihari,dan mungkin akan semakin memburuk sampai saat ini belum ada obat yang benar-benar menyembuhkan asma ini.

Tapi tenang saja yang kami maksud disini bukan asma yang seperti itu tapi asma kali ini itu maksudnya adalah Asal marah.asma yang asal marah ini pun belum ada obat yang benar-benar menyembuhkan.Tetapi dengan kesadaran,kesabaran dan sikap mau berubah serta mengubah kebiasaan yang asal marah,maka insyaallah akan sembuh.

Orang tua sebagaimana sebutannya orang tua adalah orang yang dalam segala hal harus lebih banyak dan lebih unggul dari anak-anaknya.kelebihan dan keunggulan orangtua dari anak-anaknya bisa dilihat dari kedewasaan,pengalaman

\footnotetext{
${ }^{5} \mathrm{http} / / / \mathrm{www}$.puskel.com/5-jenis-perlakuan-kekerasan-terhadap-anak/
} 
hidup,kebijaksanaan,rasa cinta ,ilmu pengetahuan ,kewibawaan ,kesabaran ,kecakapan hidup,amal-amalan ,ibadahnya,dan sebagainya. ${ }^{6}$

Adapun saran yang tepat agar tidak mengidap penyakit ini yaitu:

a. Kita harus dapat menanamkan niat yang kuat bahwa kita dapat mengubah sikap dan ingin sembuh dari penyakit ini.

b. Setelah menetapkan niat untuk mengubah kebiasaan asma ini,kita harus bertekad dalam diri dengan membuat program atau perencanaan perubahan .

c. Kalau ada hal-hal yang membuat kita merasa jengkel,menyebalkan dan hal lain yang ingin membuat kita marah,maka tahan kuat-kuat agar kita jangan sampai marah dan mengeluarkan kata-kata yang tidak baik.

d. Tanamkan sikap keyakinan bahwa sebagai orangtua kita menginginkan bahtera rumah tangga yang harmonis. ${ }^{7}$

2. TBC (terlalu bawel dan cerewet)

Yang dimaksud TBC kali ini bukan jenis penyakit tapi merupakan suatu pola yang membahayakan bagi perkembangan anak.jenis TBC inilah yang sering diderita oleh para orangtua terutama oleh seorang ibu.dan anak-anaklah yang merasakan efek sampingnya.Karena sebagai orang tua merasa dirinya memang pantas untuk berbuat seperti itu dengan alasan demi kebaikan anak.Disadari atau tidak dalam pola komunikasi dan intraksi kita dengan anak banyak yang berupa intruksi,perintah, aturan ,larangan,perbandingan,dan penilaian. ${ }^{8}$

Menurut versi mereka orang tua dikatakan bawel dan cerewet jika terindikasi mempunyai perilaku sebagai berikut:

a. Terlalu banyak mengatur.

b. Bisanya hanya menyuruh saja.

c. Banyak melarang.

d. Banyak mengomel.

e. Banyak menekan atau mengancam.

f. Banyak memberi kata-kata negatif.

g. Terlalu khawatir.

\footnotetext{
${ }^{6}$ Rahmat Affandi,Hentikan kebiasaan berbahaya bagi anak,(Jakarta:PT.Gramedia,2011),cet.ke-1;hal 78

${ }^{7}$ Ibid, hal 11-13

${ }^{8}$ Ibid, hal 18
} 
h. Nada bicaranya tinggi atau keras.

i. Menganggap sebagai anak kecil.

Efek samping terhadap anak dari penyakit ini yaitu:

a) Anak tumbuh menjadi pribadi yang tertekan.

b) Anak menjadi lebih pendiam.

c) Kreatifitas dan potensi anak terbenam,tidak tereksplor.

d) Anak kurang percaya diri.

e) Anak akan selalu bergantung pada orang lain.

f) Secara tidak langsung mengajarkan kepada anak cara mendidik yang salah.

g) Anak akan meniru bahkan akan lebih bawel dan cerewet kepada teman sebayanya atau kepada adiknya.

Setelah mengetahui beberapa indikasi orang tua terjangkit TBC,maka berikut saran yang tepat:

a. Sebaiknya orang tua tidak banyak mengatur.

b. Orang tua sebaiknya tidak banyak menyuruh.

c. Orang tua tidak banyak melarang.

d. Orang tua jangan hanya mengomel terus.

e. Orang tua harus lebih memberikan semangat.

f. Jangan terlalu mengkhawatirkan anak.

g. Orang tua harus memahami dunia anak. ${ }^{9}$

3. Kusta (kurang sentuhan cinta)

Sebagian besar orang tua merasa bahwa mereka telah memberikan segalanya untuk anak-anaknya.semua keinginan anak-anak terpenuhi dengan baik,semua keperluan sekolah dibelikan dan disediakan dengan baik pula.sebagian besar orang tua merasa bahwa tugas dan kewajiban sebagai orang tua mengurus anak-anaknya sudah ditunaikan dengan memberi apa yang dibutuhkan oleh mereka. ${ }^{10}$ padahal itu semua adalah kesalahan pahaman yang sering terjadi dengan menganggap bahwa rasa cinta orang tua kepada anak-anaknya dengan memberikan apa yang di inginkannya danmemenuhi kebutuhan fisiknya.padahal cinta hakiki yang tidak

${ }^{9}$ Ibid,hal 22-37

${ }^{10}$ Ibid, hal 41 
disadari oleh kebanyakan orang tua adalah adanya pemberian pemahaman ,emosi,dan perhatian secara batiniah. ${ }^{11}$

Berikut adalah indikator-indikator orang tua yang mengidap penyakit kusta yaitu:

1) Memberikan anak di bawah asuhan orang lain.

2) Menjelek-jelekan anak.

3) Terlalu mengekang (posesif).

4) Memberikan semua keinginan anak.

5) Memarahi anak yang tidak sengaja merusak mainannya.

6) Membandingkan dengan anak lainnya.

7) Banyak menyalahkan anak.

8) Kurang memberi penghargaan.

9) Membicarakan sifat dan karakter anak di depan orang lain.

10) Memberikan hukuman tidak pada tempatnya.

11) Terlalu memanjakan dan tidak melatih anak bekerja.

12) Kurang mendoakan anak.

Kalau orang tua menghendaki anak-anaknya tumbuh menjadi apa yang diidamkan ,maka kuncinya adalah dengan memberikan dan membekalinya dengan sentuhan cinta.cinta dapat melahirkan energi luar biasa,menumbuhkan kreativitas yang tinggi ,dan tentu kecerdasannya akan meningkat.

Dengan cinta yang diberikan oleh orang tua kepada anaknya ,dengan tutur kata yang lembut yang menyejukkan, dengan kehangatan sikap yang menentramkan ,maka anak-anak kita akan memberikan pengalaman positif yang diterimanya selama ini kepada anak-anaknya kelak. ${ }^{12}$

4. Kudis(kurang disiplin)

Bagi anak ,aktifitas terbanyak adalah dirumah.Oleh karena itu pendidikan terbanyak dilakukan di dalam rumah.karna aktifitas anak banyak dihabiskan di rumah,maka orang tua perlu membuat suatu jadwal kegiatan yang diteratur dan disepakati bersama antara orang tua dan anaknya. Mulai bangun tidur,waktu

${ }^{11}$ Ibid,hal 42-43

${ }^{12}$ Ibid, hal 49-48 
belajar,waktu bermain,waktu untuk makan ,mengerjakan tugas sekolah,waktu sholat dan lain sebagainya.

Padahal orang tua sendiri kadang inkonsisten dalam menerapkan aturan,seperti orang tua kepada anak melarang merokok tapi mereka sendiri merokok.Disiplin merupakan salah satu unsur pokok dalam upaya mencapai kualitas keberhasilan manajemen disamping unsur pemahaman dan kesungguhan.

Adapun cara menerapkan disiplin dengan cara sebagai berikut:
a. Mengenal diri sendiri
b. Mendisiplinkan diri.
c. Memimpin dengan keteladanan.
d. Menanamkan semangat kemandirian.
e. Menghindari sikap dan perilaku negatif.
f. Tegas dan tidak plin plan.
g. Konsisten pada aturan yang dibuat.
h. Memberikan hadiah atau pujian yang edukatif atas pencapaian anak.
i. Memberikan hukuman yang konstruktif atas kesalahan dan kelalaian anak.
j. Anggap disiplin sebagai cermin ibadah. ${ }^{13}$

5. Pikun(pikiran kuno)

Anak adalah amanah,anak adalah anugrah dari Sang pencipta.Orang tua harus bertanggung jawab secara moral kepada Sang pencipta,terutama dalam hal mendidiknya.kesungguhan orang tua dalam mendidik anak merupakan langkah awal keberhasilan orang tua dalam membina rumah tangga dan keluarganya,terlebih apabila anak-anak menuruti perintah orang tuanya, mengerti akan tugas,dan menuruti perintah agamanya.

Tetapi masih banyak orang tua yang menerapkan cara-cara dan pola-pola dalam dalam mendidik anak, bukan berarti cara dan pola yang lama tidak baik, hanya saja kebanyakan orang tua mendidik atas dasar turun temurun. ${ }^{14}$

6. Aids(Asal itu duit sikat)

\footnotetext{
${ }^{13}$ Ibid, hal 55-65

${ }^{14}$ Ibid, hal 70-71
} 
Fenomena yang banyak terjadi sekarang dan seolah sudah menjadi suatu paham,bahwa"waktu adalah uang ".Begitu pentingnya nilai uang bagi kehidupan sehingga banyak orang yang yang menghabiskan hidup dan waktu untuk mencari uang.meskipun cara untuk mendapatkannya tidak halal ${ }^{15}$.Karna hal itu pasti akan mempengaruhi kepribadian anak dengan pikiran yang tidak baik ,pikiran negatif,anak dengan kepribadian yang selalu ingin menghalalkan segala cara.

7. Bisulan(Bapak ibu sibuk urusan keluarga terlantar)

Banyak kasus anak yang broken home,karna dirumahnya tidak pernah mendapat perhatian yang maksimal.Mereka pun sering kali tidak pernah berkesempatan ngobrol sama orang tua dan bahkan sering ketika bertemu malah tidak perhatian dan kasih sayang yang ditunjukan akan tetapi tuntutan harus begini begitu sehingga anak itu akan tertekan dan terabaikan. ${ }^{16}$

8. Kurapan(kurang respon atau pencapaian anak)

Memberikan respon,terutama respon positif atau pencapaian anak jangan diasumsikan sebagai keharusan yang memberatkan.dan itupun bukan merupakan suatu hal yang rumit karna memang mudah dan murah. ${ }^{17}$

9. Polip(pola asuh inkonsisten dan permisif)

Intraksi antara orang tua dan anak-anaknya dapat ditunjukan dengan bagaimana cara orang tua bersikap dan berperilaku baik terhadap anak-anaknya.jadi sebagai orang tua hendaknya sangat berhati-hati dalam menerapkan pola asuh. ${ }^{18}$ pola asuh yang diterapkan oleh orang tua hendaknya dinamis , artinya harus sesuai tingkat perkembangan anak. ${ }^{19}$

10. Batuk(bicara asal nyeletuk)

Sebagai orang tua yang baik ,maka akan selalu berusaha untuk selalu menjaga lidah.Walaupun ada istilah lidah tak bertulang,tetapi kalau di kelola dengan baik ,lidah akan lebih kejam dari pada sebuah pedang. ${ }^{20}$

Adapun resep untuk penyakit ini adalah

\footnotetext{
15 Ibid,hal 79-80

${ }^{16}$ Ibid,hal 92

${ }^{17}$ Ibid, hal 101-102

${ }^{18}$ Ibid, hal 106

${ }^{19}$ Ibid, hall12

${ }^{20}$ Ibid, hal 120
} 
a) Orang beriman lebih memilih diam dan sekali bicara banyak mengandung manfaat dan mengandung kebenaran.

b) Janganlah banyak kata sebab disitu pasti banyak dusta.

c) Banyak mendengar hal yang positif.

d) Segera minta maaf jika asal nyeletuk ketika bicara pada anak.

e) Mulailah mengganti kata kasar menjadi kata yang benar dan halus ${ }^{21}$.

11. Luka (lupa kebesaran Allah)

Bukan berarti kita lupa akan nikmat Allah ,tapi kadang sering kali kita tidak sadar dengan ucapan yang sering melahirkan kesombongan,takabbur dan sebagainya.

Supaya tidak mengidap penyakit ini maka kita harus sering berdzikir kita ingat bahwa semuanya tidak luput dari kebesaran dan kekuasaan Allah. ${ }^{22}$

12. Gatal(Gangguan mental)

Adapun ciri-ciri anak yang terkena gangguan mental yaitu
a.Mudah tersinggung
b. Memperhatikan diri sendiri berlebihan
c.Bersikap kacau dan cemas
d. Suka menyendiri
e.Bersikap agresif terhadap diri sendiri
f. Mudah sekali terpengaruh
g. Emosinya stabil
h. Rasa humor kurang stabil ${ }^{23}$

13. Tipus(Tidak peduli urusan sekolah)

Banyak sekali yang terjadi di kalangan orang tua yang tidak begitu mempedulikan urusan sekolah dan lebih mementingkan urusan diri sendiri. ${ }^{24}$

14. Mimisan (mikir-mikir dan cari-cari alasan)

Salah satu kriteria orang tua yang asyik yaitu yang smart .dan setiap kali anak menanyakan sesuatu baik dari segi pengatahuan maupun pelajaran kita harus

\footnotetext{
${ }^{21}$ Ibid, hal 122-125

22 Ibid, hal 130

${ }^{23}$ Ibid, hal 137

${ }^{24}$ Ibid, hal 147
} 
bisa menjawab dan mencoba menjelaskan ,dan tidak selalu mencari-cari alasan dan menghindarinya. ${ }^{25}$

15. Manja(menjaga jarak)

Menjaga jarak dalam arti agar anak tetap patuh dan hormat kepada orang tua dan tentu agar wibawa orang tua tetap terjaga.Akan tetapi tidak harus dibangun dengan menerapkan aturan yang tegas dan cenderung keras. ${ }^{26}$

\section{F. PENUTUP}

Dapat disimpulkan bahwa banyak sekali masyarakat yang kurang memahami dan mengerti akan pola pendidikan terhadap anak.dan seringkali banyak yang menerapkannya dengan cara kekerasan terhadap anak,padahal dengan cara seperti itu sangatlah berdampak buruk bagi perkembangan anak.baik dari segi mental maupun kondisi jasmani rohaninya.

Banyak orang tua yang kurang memahami akan arti kekerasan tersebut,mungkin awalnya bertujuan agar anak itu bisa disiplin dan patuh terhadap mereka.akan tetapi mereka banyak salah ambil sikap sehingga banyak orang tua yang menganggap bahwa cara yang diberikan tidak berdampak apa-apa ,padahal itu sangat berpengaruh bagi perkembangan anak.

Jadi sangatlah berpengaruh bagi anak, jika semua sikap yang diberikan terhadap anak selalu berupa kekerasan yang terus menerus.oleh sebab itu sangatlah penting bagi orang tua untuk memahami tulisan ini.

${ }^{25}$ Ibid, hal 154

${ }^{26} \mathrm{Ibid}$, hal $161-162$ 
Jurnal Keislaman, Vol. 2, No. 2, September

\section{DAFTAR PUSTAKA}

Affandi,Rahmat.2011.Hentikan kebiasaan Berbahaya Bagi Anak . jakarta :

PT.Gramedia.

http://www.puskel.com/5-jenis-perlakuan-kekerasan-terhadap-anak/

http://www.smallcrab.com/anak-anak/550-beberapa-jenis-kekerasan-pada-anak

http://iin-green.web.id/2010/05/08/definisi-kekerasan-terhadap-anak/

http://www.psychologymania.com/2012/07/pengertian-kekerasan-terhadap-anak.html

http://www.duniapsikologi.com/latar-belakang-kekerasan-pada-anak/ 